\title{
PENGARUH MODEL PEMBELAJARAN BERBASIS PROYEK TERHADAP PRESTASI BELAJAR KIMIA SISWA KELAS XI IPASMAN 1 NARMADATAHUN PELAJARAN 2013/2014
}

\author{
Nurbaiti Rindang Utami ${ }^{1}$, YayukAndayani ${ }^{2}$, Muntari ${ }^{2}$ \\ ${ }^{1}$ Alumni Program Studi Pendidikan Kimia FKIP Universitas Mataram \\ ${ }^{2}$ Program Studi Pendidikan Kimia FKIP Universitas Mataram \\ Email:ryen_oetamie@yahoo.com
}

\begin{abstract}
Abstrak : Penelitian ini bertujuan untuk mengetahui pengaruh model pembelajaran berbasis proyek terhadap prestasi belajar kimia siswa kelas XI IPA SMAN 1 Narmada Tahun Pelajaran 2013/2014. Penelitian ini menggunakan desain penelitian eksperimen semu dengan rancangan post test only control group design. Pengambilan sampel dilakukan dengan teknik cluster random sampling karena anggota populasi sudah homogen berdasarkan data nilai ujian semester ganjil siswa kelas XI IPA. Kelas XI IPA 1 sebagai kelas eksperimen menggunakan model pembelajaran berbasis proyek dan kelas XI IPA 3 sebagai kelas kontrol menggunakan model pembelajaran konvensional. Post test digunakan sebagai instrumen utama penelitian, selain itu portofolio juga digunakan sebagai instrumen kedua penelitian ini. Hasil uji beda (uji-t) post test dengan taraf signifikan 5\% menunjukkan $\mathrm{t}_{\text {hitung }}(4,105)>\mathrm{t}_{\text {tabel }}(2,000)$ sehingga $\mathrm{H}_{0}$ ditolak. Uji-t dilakukan juga pada hasil portofolio yang menunjukkan $t_{\text {hitung }}(2,89)>t_{\text {tabel }}(2,000)$. Berdasarkan kedua hasil tersebut, dapat disimpulkan bahwa model pembelajaran berbasis proyek memberikan pengaruh yang lebih baik dibandingkan dengan model konvensional terhadap prestasi belajar kimia siswa kelas XI IPA SMAN 1 Narmada Tahun Pelajaran 2013/2014.
\end{abstract}

Kata kunci: Model pembelajaran berbasis proyek, prestasi belajar kimia

\begin{abstract}
The objective of the research was to know the effect of Project-Based Learning towards the student's chemistry learning achievement class XI IPA of SMAN 1 Narmada in 2013/2014 academic year. This research used a quasi-experimental research design with the design of post-test only control group design. Sampling was done by cluster random sampling technique because members of populations have homogeneous based on data value semester exams of class XI science students. Class XI IPA 1 as experimental group was threated by project-based learning model and class XI IPA 3 as control group was threated by conventional learning models. Post test is used as an basic instrument. In addition, the portofolio is as a second instrument of this research.. The results of post-test hypothesis test using a different test ( $\mathrm{t}$-test) with a significance level of $5 \%$ showed $\mathrm{t}_{\text {acc }}(4.105)>\mathrm{t}_{\text {table }}(2.000)$ so that $\mathrm{H}_{0}$ is rejected. Hypothesis testing is also performed on the results of portfolio show $t_{\text {acc }}(2.89)>t_{\text {table }}(2.000)$. Based on these results, we can conclude that project-based learning model provides give a better effect than the conventional models of the student's chemistry learning achievement class XI IPA of SMAN 1 Narmada in 2013/2014 academic year.
\end{abstract}

Keywords : project-based learning model, the students's chemistry achievement learning

\section{PENDAHULUAN}

Pembelajaran berbasis proyek atau Project Based Learning (PjBL) merupakan model pembelajaran yang berorientasi pada kerangka kerja teoritik konstruktivisme. Berdasarkan informasi yang diperoleh dari salah satu guru kimia di SMAN 1 Narmada, penggunaan model pembelajaran konvensional masih mendominasi dalam kegiatan belajar-mengajar, sehingga keterlibatan siswa dalam kegiatan pembelajaran masih kurang. Hal ini berdampak pada prestasi belajar siswa yang rendah. Lebih lanjut dijelaskan bahwa mata pelajaran kimia merupakan mata pelajaran yang bersifat abstrak, sehingga membutuhkan keterlibatan guru secara lebih komunikatif dalam menjelaskan. Kondisi inilah yang menimbulkan kesan bahwa kimia merupakan mata pelajaran yang sulit, baik untuk dipelajari maupun diajarkan. Penggunaan model yang sesuai dan lebih variatif dapat menjadikan kimia bisa menjadi salah satu mata pelajaran yang cukup menarik. Mengatasi masalah tersebut, perlu dikembangkan suatu model pembelajaran yang dapat melibatkan siswa secara lebih aktif baik secara fisik maupun mental. Salah satu model pembelajaran yang dapat digunakan untuk memenuhi kebutuhan tersebut adalah dengan menggunakan model pembelajaran berbasis proyek.

Hasil penelitian Siwa dkk [1] menunjukkan bahwa terdapat perbedaan hasil belajar keterampilan proses sains antara kelompok siswa yang mengikuti model pembelajaran proyek dengan kelompok siswa yang mengikuti model pembelajaran konvensional dengan nilai $\mathrm{F}_{\mathrm{A}}=38,5313$ pada taraf signifikansi 0,05. Hasil penelitian lain yang dilakukan Amanda dkk [2] memberikan kesimpulan bahwa terdapat perbedaan hasil belajar IPA antara siswa yang mengikuti model pembelajaran berbasis proyek dan siswa yang 
mengikuti model pembelajaran konvensional $\left(\mathrm{F}_{\mathrm{A}(\mathrm{Hitung})}=\right.$ $\left.20,688>\mathrm{F}_{\text {tabel }}=3,96\right)$. Penelitian lain yang dilakukan oleh Sastrika, dkk [3] menunjukkan bahwa terdapat perbedaan pemahaman konsep dan keterampilan berpikir kritis siswa antara siswa yang mengikuti pembelajaran berbasis proyek dan siswa yang belajar dengan model pembelajaran konvensional.

\section{METODE PENELITIAN}

Penelitian ini dilakukan di SMAN 1 Narmada dengan rancangan post test only control group design. Variabel bebas dalam penelitian ini adalah model pembelajaran berbasis proyek pada kelompok eksperimen dan model pembelajaran konvensional pada kelompok kontrol, sedangkan variabel terikatnya adalah prestasi belajar kimia siswa yang dinilai dari hasil post test dan portofolio. Pengambilan sampel menggunakan teknik cluster random sampling sehingga diperoleh kelas XI IPA 1 sebagai kelas eksperimen, dan kelas XI IPA 3 sebagai kelas kontrol. Hasil post test maupun portofolio digunakan untuk mengetahui prestasi belajar siswa dengan melakukan uji hipotesis menggunakan uji-t.

Instrumen yang digunakan dalam penelitian ini adalah instrumen penilaian portofolio dan instrumen penilaian kognitif (post test). Kisi-kisi penilaian portofolio disusun berdasarkan kompetensi dasar, materi, indikator dan penilaian yang digunakan. Hasil belajar kognitif (pengetahuan) siswa diukur menggunakan instrumen hasil belajar berupa tes objektif pilihan ganda (multiple choice test), dengan ranah kognitif $\mathrm{C} 1-\mathrm{C} 4$, kemudian di uji validitas dan reliabilitasnya. Validitas item soal diuji menggunakan korelasi point biserial, sedangkan reliabilitasnya menggunakan teknik KR 20 (Kuder Richardson).

\section{HASIL DAN PEMBAHASAN Hasil Portofolio}

Perbedaan nilai rata-rata portofolio siswa antara kelas eksperimen dan kelas kontrol ditampilkan pada Gambar 1.
Nilai rata-rata kelas eksperimen lebih tinggi dibandingkan dengan nilai rata-rata kelas kontrol. Proses yang terjadi di kelas eksperimen yang menerapkan model pembelajaran berbasis proyek lebih baik dibandingkan dengan proses yang terjadi di kelas kontrol yang masih menggunakan model pembelajaran konvensional (ceramah dan penugasan). Proses dalam pembelajaran berbasis proyek memiliki tahapan yang sesuai dengan pendekatan yang berpusat pada siswa (student centered approach), sehingga menuntut siswa menemukan sendiri pengetahuannya. Di lain pihak, model pembelajaran konvensional masih menjadikan guru sebagai pusat pembelajaran, sehingga dalam proses pembelajaran guru lebih mendominasi. Perbedaan perlakuan yang diberikan di kelas eksperimen dan kelas kontrol menunjukkan adanya proses pembelajaran yang berbeda pula, sehingga proses dalam hal ini menjadi hal yang penting.

Tugas-tugas yang diberikan di kelas eksperimen maupun kelas kontrol diperiksa satu persatu dan kemudian dibandingkan hasilnya. Jika melihat Gambar 1, kita bisa mengetahui perbedaan kedua kelas tersebut, nilai rata-rata tugas untuk kelas eksperimen lebih tinggi dari pada nilai rata-rata kelas kontrol. Hal ini disebabkan adanya perbedaan model pembelajaran yang diterapkan pada kedua kelas tersebut, dengan menggunakan model pembelajaran berbasis proyek, siswa belajar lebih mandiri sehingga mereka dapat menemukan sendiri pengetahuan yang baru dari apa yang mereka lihat.

Proyek utama yang diberikan mengenai pembuatan alat penjernih air sederhana dan wawancara dengan narasumber mengenai pencemaran udara. Beberapa pertanyaan yang diberikan dalam Lembar Kerja Proyek dikerjakan pada waktu diskusi di kelas, kemudian setiap kelompok mempresentasikan hasil diskusi mereka. Berbeda dengan kelas eksperimen, kelas kontrol hanya diberikan Lembar Kerja Siswa yang didiskusikan bersama kelompok mereka masing-masing. Topik yang diberikan sama dengan kelas eksperimen, namun siswa hanya mendiskusikan pertanyaan-pertanyaan yang diberikan tanpa adanya

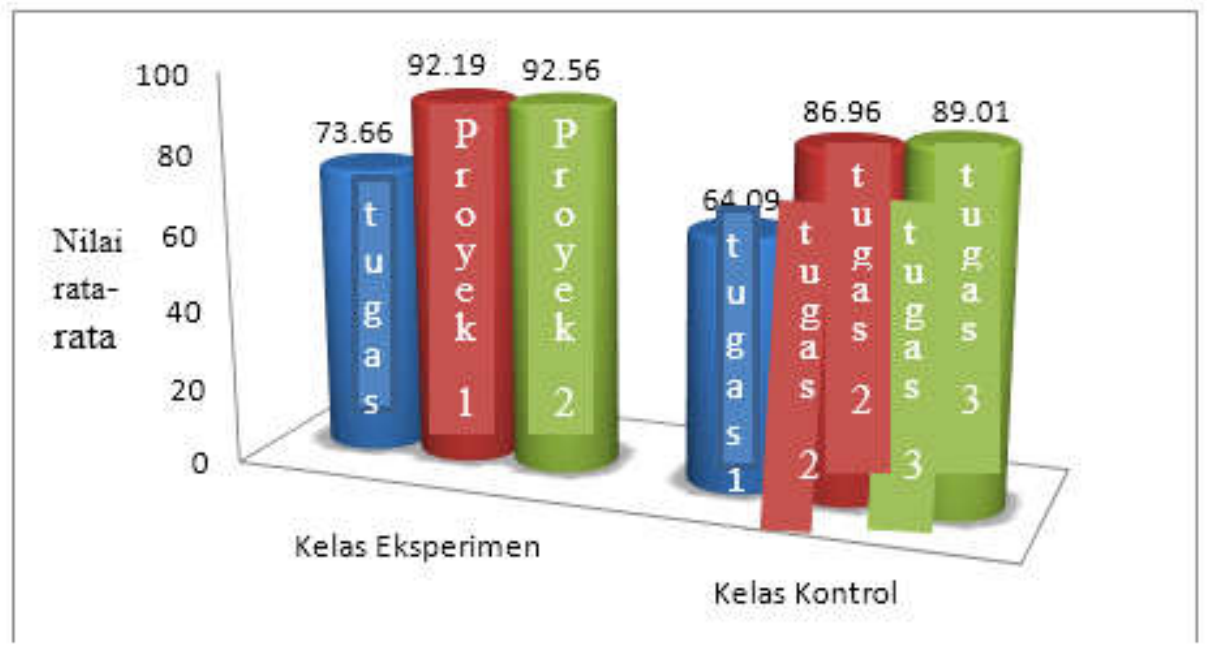

Gambar 1 Nilai rata-rata hasil portofolio kelas eksperimen dan kelas kontrol 
proyek yang harus dilakukan. Kelas eksperimen maupun kelas kontrol diberi kesempatan untuk mempresentasikan hasil diskusi mereka. Hasil proyek siswa di kelas eksperimen maupun hasil diskusi siswa di kelas kontrol dinilai dan dibandingkan. Jika melihat gambar 5.2, nilai rata-rata proyek siswa di kelas eksperimen lebih tinggi dari pada nilai rata-rata tugas diskusi siswa di kelas kontrol. Proyek yang diberikan di kelas eksperimen dapat meningkatkan antusiasme siswa untuk belajar. Hal ini dapat dilihat dari keseriusan siswa mengerjakan proyek mereka.

Prestasi belajar yang meningkat diakibatkan adanya model pembelajaran proyek yang diterapkan terhadap kelas eksperimen. Hal ini terjadi karena siswa tertarik dan lebih termotivasi dengan pembelajaran berbasis proyek yang dapat dilihat dari proyek yang telah dikerjakan siswa. Adanya motivasi yang tinggi dari siswa dapat menumbuhkan keinginan siswa dalam mengikuti pembelajaran sehingga hasil belajar yang diperoleh akan lebih baik. Adapun dari hasil observasinya yaitu ketika proses pembelajaran berlangsung terlihat bahwa siswa dapat merespon pembelajaran dengan baik dan aktivitas siswa dalam menyelesaikan proyek dan presentasi sudah cukup baik serta mereka cukup senang dan aktif dalam mengikuti pembelajaran yang dilaksanakan.

Model pembelajaran berbasis proyek memiliki banyak keuntungan, diantaranya adalah dapat meningkatkan motivasi, meningkatkan kemampuan pemecahan masalah, meningkatkan kolaborasi, dan meningkatkan keteramnilan mengelola sumber 561. meningkatkan kolaborasi antar teman kelompoknya untuk menghasilkan produk yang baik. Selain itu, melalui proyek siswa dapat meningkatkan keterampilannya dalam mengelola sumber. Hal ini dapat dilihat dari informasi yang diberikan didapat dari berbagai sumber yang ada.

Pembelajaran berbasis proyek sangat berkaitan dengan teori konstruktivistik, karena siswa mengkonstruk atau membangun sendiri pengetahuannya dari proyek yang dilakukan. Melalui banyaknya aktivitas yang dilakukan oleh siswa selama proses pembelajaran, dapat lebih meningkatkan pemahaman siswa terhadap materi, karena siswa ikut terlibat langsung dalam kegiatan pembelajarannya serta dapat memberikan pengalaman langsung bagi siswa sehingga pengetahuan yang diperoleh dapat lebih bermakna. Siswa juga akan terbiasa untuk menyelesaikan proyek sesuai dengan masalah yang telah didapat. Hal ini dapat dilihat dari proyek yang sudah diselesaikan oleh masing-masing kelompok dengan sangat baik. Presentasi atas proyek yang didapat juga akan melatih keterampilan siswa dalam mengungkapkan gagasannya sehingga nantinya pemahaman sekaligus pengetahuan siswa dapat terbentuk dengan sendirinya. Hal ini sesuai dengan teori konstruktivistik yang mendasari model pembelajaran berbasis proyek ini.

\section{Hasil Post Test}

Kelas eksperimen maupun kelas kontrol diberi post test di akhir pertemuan, nilai rata-rata hasil post test kelas eksperimen dan kelas kontrol diberikan pada Gambar 2 .

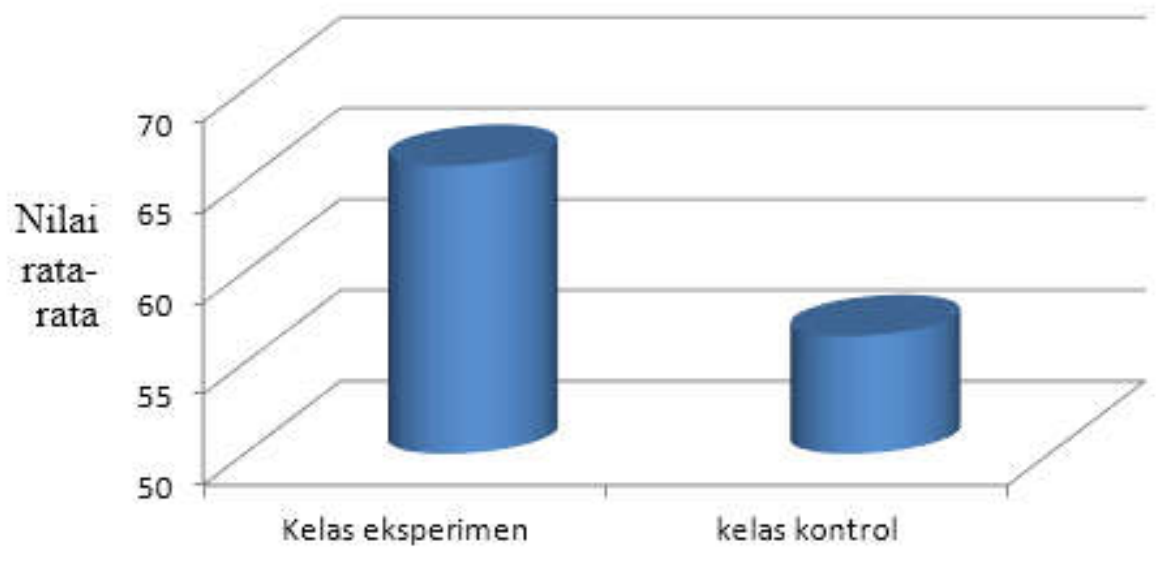

Gambar 2. Nilai rata-rata hasil Post Test kelas eksperimen dan kelas kontrol

Pembelajaran berbasis proyek menuntut siswa untuk dapat memecahkan masalah yang berkaitan dengan kehidupan sehari-hari. Seperti pada proyek I, salah satunya adalah pembuatan alat penjernih air sederhana. Siswa dituntut untuk dapat membuat alat penjernih air yang bahanbahannya dari lingkungan sekitar. Melalui proyek ini, siswa dapat memahami koloid dengan bahasanya sendiri. Hal ini dapat dilihat dari hasil penilaian proyek yang rata-rata aspek proyeknya terpenuhi dengan sangat baik. Proyek yang dilakukan siswa secara berkelompok juga dapat
Gambar 2 tersebut menunjukkan bahwa nilai rata-rata post test materi sistem koloid kelas eksperimen lebih tinggi dibandingkan dengan nilai rata-rata kelas kontrol. Hasil uji-t menunjukkan bahwa Ho ditolak, sehingga model pembelajaran berbasis proyek memberikan pengaruh yang lebih baik dibandingkan dengan model konvensional (ceramah dan diskusi) terhadap prestasi belajar kimia siswa kelas XI IPA SMAN 1 Narmada Tahun Pelajaran 2013/2014.

Model pembelajaran berbasis proyek melibatkan pemecahan masalah tugas atau proyek yang melatih siswa 


\section{J. Pijar MIPA, Vol. VIII No.2, September : 70 - 75}

untuk aktif membangun dan mengatur pembelajarannya, serta menjadikan siswa lebih realistis. Di lain pihak, model pembelajaran konvensional jarang melibatkan pengaktifan pengetahuan awal dan jarang memotivasi siswa untuk memproses pengetahuannya, akibatnya pembelajaran menjadi kurang bermakna dan siswa menjadi pasif dalam pembelajaran. Adanya pembelajaran berbasis proyek yang diterapkan dapat meningkatkan kemampuan pemecahan masalah. Hal ini sejalan dengan penelitian yang dilakukan oleh Arimbawa dkk [4] yang memberikan kesimpulan bahwa terdapat perbedaan kemampuan pemecahan masalah IPA antara kelompok peserta didik yang belajar dengan model pembelajaran berbasis proyek dan konvensional. Penelitian lain yang dilakukan oleh Cawi dkk [5] menyimpulkan bahwa terdapat perbedaan hasil belajar menggambar layout dekorasi interior \& eksterior siswa yang mengikuti model pembelajaran berbasis proyek dan siswa yang mengikuti model pembelajaran konvensional.

Siswa yang mengikuti model pembelajaran berbasis proyek mendapatkan kesempatan lebih luas untuk belajar secara mandiri. Guru lebih banyak berposisi sebagai pengarah, pembimbing, pemberi fasilitas, dan motivator dalam pembelajaran. Keadaan seperti ini sangat berpotensi untuk membangun konsep pada diri siswa secara mandiri,

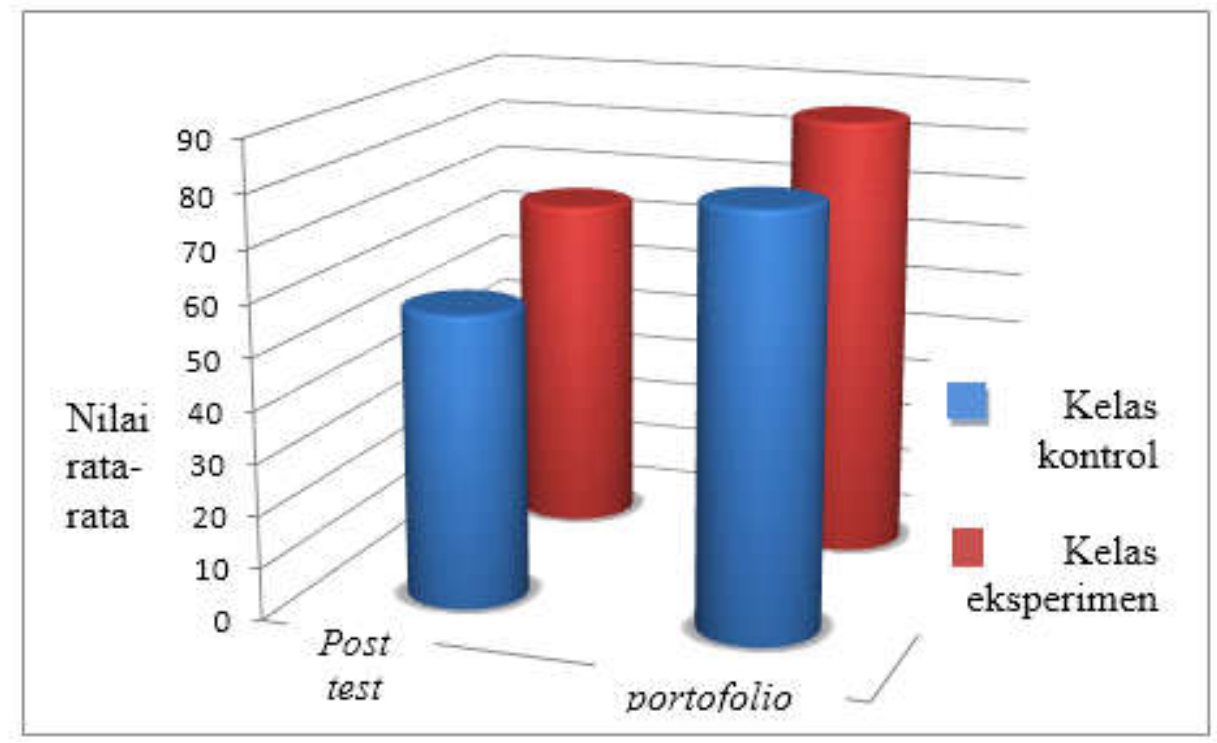

Gambar 3. Nilai rata-rata Post Test dan Portofolio

Tabel 1 Perbedaan penilaian post test dan penilaian portofolio

\begin{tabular}{|l|l|l|}
\hline No & \multicolumn{1}{|c|}{ Penilaian portofolio } & \multicolumn{1}{|c|}{ Penilaian post test } \\
\hline 1 & Lebih menekankan pada kemajuan proses & Hanya menilai hasil akhir \\
\hline 2 & $\begin{array}{l}\text { Dapat mengevaluasi kebutuhan, minat, } \\
\text { kemampuan akademik, dan karakteristik siswa } \\
\text { secara individual }\end{array}$ & $\begin{array}{l}\text { Hanya mengevaluasi siswa dalam } \\
\text { kemampuan kognitif tingkat rendah }\end{array}$ \\
\hline 3 & $\begin{array}{l}\text { Siswa ikut serta dalam menilai kemajuan yang } \\
\text { dicapai dalam penyelesaian berbagai tugas yang } \\
\text { dinilai }\end{array}$ & $\begin{array}{l}\text { Penilaian hanya dilakukan oleh guru dengan } \\
\text { masukan yang terbatas }\end{array}$ \\
\hline 4 & $\begin{array}{l}\text { Lebih otentik atau sesuai dengan kenyataan yang } \\
\text { ada karena ada bukti-bukti hasil kinerja siswa } \\
\text { yang dikumpulkan }\end{array}$ & $\begin{array}{l}\text { Hasil sulit dipertanggungjawabkan dengan } \\
\text { baik }\end{array}$ \\
\hline 5 & $\begin{array}{l}\text { Menilai siswa berdasarkan hasil kerja yang } \\
\text { berkaitan dengan kinerja yang dinilai }\end{array}$ & $\begin{array}{l}\text { Menilai siswa berdasarkan pencapaian tujuan } \\
\text { tertentu }\end{array}$ \\
\hline 6 & $\begin{array}{l}\text { Lebih rumit karena portofolio siswa cukup } \\
\text { banyak yang harus dinilai }\end{array}$ & Lebih sederhana \\
\hline 7 & $\begin{array}{l}\text { Mewujudkan proses penilaian yang kolaboratif } \\
\text { gewoses penilaian tidak ada kerjasama antara } \\
\text { guru dengan siswa }\end{array}$ \\
\hline
\end{tabular}


sehingga pembelajaran menjadi lebih bermakna. Seseorang belajar jauh lebih baik melalui keterlibatannya secara aktif dalam proses belajar, yakni berpikir tentang apa yang dipelajari dan kemudian menerapkan apa yang telah dipelajari dalam situasi nyata. Model pembelajaran berbasis proyek ini lebih fokus pada pengkonstruksian pengetahuan siswa dari informasi penting yang diperoleh melalui proyek.Penilaian post test dan portofolio

Penilaian yang dilakukan menggunakan penilaian post test dan portofolio siswa yang disajikan sekaligus dalam Gambar 3 .

Penilaian portofolio lebih menekankan pada proses yang telah dilakukan siswa. Setiap tugas maupun proyek yang telah diselesaikan dinilai dengan penilaian portofolio, sehingga setiap aspek yang ada dapat dipertanggungjawabkan dengan baik. Tugas-tugas yang diberikan lebih terstruktur sehingga penilaian portofolio mampu menampilkan kemampuan siswa secara menyeluruh. Lain halnya dengan penilaian post test, penilaian ini menekankan pada hasil yang tidak dapat menggambarkan kemampuan siswa secara menyeluruh. Hal ini berkaitan dengan apa yang dinilai, pada post test siswa dituntut untuk mempelajari materi sistem koloid secara keseluruhan dan tes yang diberikan sekaligus menghimpun semua materi koloid. Berbeda dengan portofolio yang dinilai secara bertahap sesuai dengan tugas maupun proyek yang diberikan, sehingga kemampuan siswa benar-benar dapat terukur dengan baik. Berdasarkan pembahasan sebelumnya, berikut ditampilkan Tabel 1 tentang perbedaan antara penilaian post test dengan penilaian portofolio [7].

Penilaian portofolio yang lebih menekankan pada proses yang dilakukan siswa akan mendukung hasil post test yang merupakan ukuran ketercapaian indikator pembelajaran. Melalui proses yang baik, maka hasil yang didapat juga baik. Tabel 1 menunjukkan bahwa penilaian portofolio siswa memiliki lebih banyak kelebihan jika dibandingkan penilaian post test yang biasa digunakan oleh guru untuk memberikan penilaian kepada siswa.

Berdasarkan pedoman yang disusun oleh Departemen Pendidikan Nasional Direktorat Jenderal Pendidikan Dasar dan Menengah [8], penggunaan portofolio untuk penilaian memiliki banyak manfaat, beberapa diantaranya: portofolio menyajikan atau memberikan bukti yang lebih jelas atau lebih lengkap tentang kinerja siswa dari pada hasil tes di kelas, portofolio dapat merupakan catatan penilaian yang sesuai dengan program pembelajaran yang baik, portofolio merupakan catatan jangka panjang tentang kemajuan siswa, portofolio memberikan gambaran tentang kemampuan siswa. Buktibukti mengenai kinerja siswa dapat dilihat dari tugas-tugas maupun proyek yang telah dikerjakan siswa yang kemudian dinilai menggunakan penilaian portofolio. Portofolio juga dapat memberikan gambaran yang lebih jelas tentang kemampuan siswa sehingga akan terlihat tahapan usaha siswa untuk mendapatkan nilai yang baik. Adanya kemajuan belajar siswa dimungkinkan karena lama-kelamaan siswa menjadi terbiasa dengan pembelajaran proyek yang diterapkan di kelas mereka. Hasil ini juga didukung dengan aktivitas siswa yang tergolong baik dengan persentase sebesar $71,11 \%$ sehingga model pembelajaran berbasis proyek dapat dilaksanakan dengan baik pula. Kondisi belajar optimal dapat meningkatkan kemampuan siswa menyerap dan mempertahankan materi pelajaran yang telah diberikan [9].

Model pembelajaran berbasis proyek memberikan pengaruh yang lebih baik dari pada model pembelajaran konvensional terhadap prestasi belajar kimia siswa untuk materi sistem koloid yang dinilai menggunakan penilaian post test maupun portofolio siswa. Melalui proses yang baik yang dapat dilihat dari hasil portofolio siswa, maka hasil belajar yang didapat juga baik.

\section{KESIMPULAN DAN SARAN Kesimpulan}

Berdasarkan hasil penelitian dan pembahasan, maka dapat disimpulkan bahwa model pembelajaran berbasis proyek memberikan pengaruh yang lebih baik dibandingkan dengan model konvensional (ceramah dan diskusi) terhadap prestasi belajar kimia siswa kelas XI IPA SMAN 1 Narmada Tahun Pelajaran 2013/2014.

\section{Saran}

Berdasarkan penelitian yang sudah dilakukan, peneliti mengajukan beberapa saran yaitu:

a. Peneliti selanjutnya dapat menggunakan model pembelajaran berbasis proyek dengan menggunakan penilaian lainnya.

b. Kepada mahasiswa (calon guru kimia) agar dapat meneliti lebih lanjut dengan menggunakan model pembelajaran berbasis proyek pada materi pokok yang lain. c. Penelitian lebih lanjut agar dapat memperhatikan faktorfaktor lain yang berpengaruh terhadap hasil belajar siswa sehingga dapat lebih menyempurnakan penelitian sebelumnya.

d. Pembuatan lembar kerja proyek, lembar kerja siswa maupun penilaiannya sebaiknya di- sempurnakan lagi.

\section{DAFTAR PUSTAKA}

[1] Siwa, I B., Muderawan, I W., Tika, I N. Pengaruh Pembelajaran Berbasis Proyek dalam Pembelajaran Kimia Terhadap Keterampilan Proses Sains Ditinjau dari Gaya Kognitif Siswa. e-Journal Program Pascasarjana Universitas Pendidikan Ganesha, 3 (2013).

[2] Amanda, N. W. Y., Subagia, I W., Tika, I N. Pengaruh Model Pembelajaran Berbasis Proyek Terhadap Hasil Belajar IPA Ditinjau dari Self Efficacy Siswa. e-Journal Program Pascasarjana Universitas Pendidikan Ganesha, 4 (2014).

[3] Sastrika, I A. K., Sadia, I W., \& Muderawan, I W. Pengaruh Model Pembelajaran Berbasis Proyek Terhadap Pemahaman Konsep Kimia dan Keterampilan Berpikir Kritis. e-Journal 
J. Pijar MIPA, Vol. VIII No.2, September : 70 - 75

Program Pascasarjana Universitas

Pendidikan Ganesha, 3 (2013).

[4] Arimbawa, P., Sadia, I W. \& Tika, I N. Pengaruh Model Pembelajaran Berbasis Proyek (MPBP) Terhadap Kemampuan Pemecahan Masalah IPA Sehari-hari Ditinjau dari Motivasi Berprestasi Siswa. E-journal Program Pascasarjana Universitas Pendidikan Ganesha, 3 (1) (2013).

[5] Cawi, I W., Marhaeni, A.A.I.N., Dantes, G.R. Pengaruh Model Pembelajaran Berbasis Projek Terhadap Hasil Belajar Menggambar Layout dengan Kovariabel Kecerdasan Spasial dan Kecerdasan Logis Matematis. e-Journal Program Pascasarjana Universitas Pendidikan Ganesha, 4 (2014).

[6] Hutasuhut, Saidun. Implementasi Pembelajaran Berbasis Proyek (Project Based Learning ) untuk Meningkatkan Motivasi dan Hasil Belajar Mata Kuliah Pengantar Ekonomi Pembangunan Pada Jurusan Manajemen FE UNIMED. Pekbis Jurnal, 2 (1): 196-207 (2010).

[7] Asmawi, Z., Agus, M. 2005. Tes dan Asesmen di $S D$. Jakarta: Universitas Terbuka.

[8] Salinan Lampiran Peraturan Menteri Pendidikan dan Kebudayaan Republik Indonesia Nomor 66 Tahun 2013 Tentang Standar Penilaian Pendidikan.

[9] Putra, Yovan P. 2010. Hipnosis Ericksonian. Jakarta: Elex Media Komputindo. 